\title{
Effect of Soil Amendment on the Functional and Pasting Properties of False Horn Plantain Flour
}

\author{
Frederick. Danso, Frances Appiah, BenK.Banful
}

\author{
Department of Horticulture, Faculty of Agriculture, College of Agriculture and Natural Resources, Kwame Nkrumah \\ University of Science and Technology, Private Mail Bag. Kumasi, Ghana.
}

\begin{abstract}
There is growing public perception that fruits from fertilized plantain plants have their organoleptic qualities reduced during food preparations. Such perception has the potential consequence of lowering production levels of the commodity in Ghana. To ascertain the veracity of this perception, a study was conducted between July 2012 and March 2015 to determine the effects of different rates of poultry manure, cocoa pod husk and NPK as soil amendments on nutritional composition, physical characteristics and functional properties of plantain pulp flour. The experimental design was a Randomized Complete Block with three replications. Flours from plantain with amended soils recorded moisture contents (8.41\% to $12.08 \%)$ which were within the acceptable levels for flours. The flour with the lowest moisture content was produced from plantain with CPH amendment (8.41\%). The protein content of false horn plantain flour was however low (3.39\% to 5.27\%). The plantain flour starch was not influenced by any of the soil amendments. On the other hand, flour produced from plantain with NPK+PM amendment had low bulk density and low water absorption capacity. Similarly, the false horn plantain flour had lower swelling power values compared to other flours.Flours from plantain with CPH amendment had lower oil absorption capacity. Flour from plantain with PM amendment was more likely to cook faster than the flour from the plantain with the other amendments. Flours from plantain with $\mathrm{NPK}+\mathrm{CPH}$ amendment would form a more stable paste because of its lower breakdown value. In conclusion, the plantain flours were comparable to known food flours and therefore could be applicable as thickening agents and also find usefulness in fufu powder preparation and baking.
\end{abstract}

Keywords - plantain, soil amendment, flour, pasting, functional properties and manure.

\section{INTRODUCTION}

The consumption of plantain is all year round whilst its production is seasonal and hence the need to reduce postharvest losses through the processing of fruits into forms with reduced moisture content. Plantain production has, for some time now, experiencing an increasing production with a correspondent increase in surplus since 2001
(Dankyeet al., 2007). It is assumed that in 2015, there will be about 912,000 Mt surpluses (MoFA SRID, 2014). These surpluses would have to be processed, exported or it will end up at the refuse dump (Dankyeet al., 2007). This is due to the highly perishable nature of plantains as result of high metabolic activity leading to fast deterioration mostly after harvest (Demirel and Turhan, 2003).

For the efficient use of plantain flours as an ingredient for the food industry it is important to investigate the effect of soil amendments to determine its impact on their chemical, nutritional composition, shelf life as well as their functional properties. Therefore, it is plausible to characterize the nutritional and chemical composition, as well as their physicochemical, physical and functional properties of plantain flours in order to make any recommendation for its usage in the food industry. It is also important to note that some companies in the manufacturing of instant plantain fufu flour import flours to Ghana in spite of the surpluses recorded in plantain production over the years (Dankyeet al., 2007). The conversion of plantain into flour which has the desired functional properties could contribute to reducing if not totally eliminating the import of flour into the country. Nonetheless, the preparation of flour from cooking banana is a surest means of value addition as well as extending the shelf life and enhancing transportation (Adeniji and Empere 2001).

Functional properties are the characteristics of food which dictate their behaviour, quality and acceptability during processing, storage, and preparation (Ishmealet al.,2011). Plantains are high in carbohydrate $(31 \mathrm{~g} / 100 \mathrm{~g})$ and have relatively low fat content $(0.4 \mathrm{~g} / 100 \mathrm{~g})$. Notwithstanding, they are important sources of vitamins and minerals (Adenijiet al., 2006), notably iron $(24 \mathrm{mg} / \mathrm{kg}$ ), potassium $(9.5 \mathrm{mg} / \mathrm{kg})$, calcium $(715 \mathrm{mg} / \mathrm{kg})$, vitamin A, ascorbic acid, thiamin, riboflavin and niacin. Unripe plantain flours are rich in dietary fiber $(8.82 \%)$ and resistant starch (16.2\%), micronutrients which enhance the reduction of blood sugar level. They are, however, low in fat and oil as well as protein (Ayodele and Erema, 2011). The flour is used in confectionery and bakery industries in the treatment of intestinal disorders. They are also used in the preparation of infant diets (Adenijiet al., 2006) 
Plantains require high amounts of nutrients for optimum growth and fruit production but these nutrients are often supplied in part by the soil (Lahav, 1995). This is one of the reasons why in the West and Central African regions, the crop is predominantly cultivated in the home gardens where it receives continuous supply of organic matter and nutrients from household refuse (Baiyeriet al., 2007). Animal manure is a source of nutrients and organic matter, which could improve soil bio-physical conditions (Munoz et al., 2004) for sustainable food production.

Improvement in soil fertility greatly influences the physical characteristics of both the plant and the fruit. Soil amendments strategy which seek to increase the nutritional status of the soil will therefore trigger a corresponding increase in the yields of crops grown on such soils (Ndukweet al., 2014).

Although it is known that organic and inorganic fertilizer levels affect nutrient composition of plantain fruit pulp (Ndukweet al., 2014), little is known about how they influence functional properties of plantain pulp flour which is widely used in production of fufu flour and other food products. However, the effects of a particular soil amendment strategy on the flour quality of fruits of false horn plantain (Apantu pa) ought to be determined, hence the need for this investigation.

\section{LITERATURE REVIEW}

Effect of fertilizer on the quality characteristics of Produce

In the experiment conducted by Premsekhar and Rajashree (2009) to determine the influence of different organic manures on the growth, yield and quality of okra.It came out that, organic manures performed better by producing quality fruits with less fibre content. Application of farm yard manure at $20 \mathrm{t} / \mathrm{ha}$ recorded fruits with less crude fibre content and less moisture content. It was noted that, application of farm yard manure might have caused accumulation of nutrients and dry matter in fruits than synthetic fertilization which resulted in better quality of fruits grown on soils amended with farm yard manure.

In other experiment, Kipkosgeiet al. (2003) researched on the effect of farmyard manure and nitrogen fertilizer on vegetative growth, leaf yield and quality attributes of black nightshade (Solanumvillosum). It was revealed that, the $B$-carotene content in the edible portions increased with increasing levels of fertilizers. This was attributed to Nitrogen facilitating the formation of chloroplasts, which are rich in $B$-carotene. Results also showed that farm yard manure increased the vitamin $\mathrm{C}$ content of edible leafy portions of Solanumvillosumwhereas inorganic nitrogen fertilizers decreased vitamin C content.

Quality Indicators of Flour
In the cooking sense, flour is in a form of powder which is derived from cereal, grains, roots and tuber and other seeds. It is the major ingredient used in the baking industries for the preparation of varieties of food products (Appiah et al., 2011). In the Middle East, North Africa, Europe and the Americas, wheat flours form integral part of their diet and are widely used in the preparations of breads and pastries. Good quality flours have higher gluten content which are able to produce lighter and softer baked products by embedding small gas bubbles. The amount of protein (gluten) in flour predicts its breadbaking quality for plain white flour Appiah et al. (2011).

\section{FUNCTIONAL PROPERTIES}

Matil (1971) defined functional property as the properties that affect the quality and acceptability of food as well as the characteristics that governs the behaviour of nutrients its composition when altered during storage, processing and preparation into various forms. Important functional properties that influences the suitability and usage of starchy stables such as plantain include; swelling power, water and oil absorption capacity, bulk density, solubility etc.

\section{PASTING PROPERTIES}

Otegbayo et al., (2006) stated that, during the heating and cooling of starch series of processes follow gelatinization which include granule rupture and subsequently polymer alignment due to mechanical sheer which finally result in pasting.

Flours are normally cooked into paste before eating, therefore the determination of pasting characteristics of flours are very essential in predicting quality index and the behavior of paste during and after cooking (Etudaiye $e t$ al., 2009).

\section{METHODOLOGY}

The experiment was conducted on the research field of Council for Scientific and Industrial Research Institute located (Horticultural Department Kwadaso Kumasi) at Kenyasi in the BrongAhafo Region of Ghana. The experiment was established as a demonstration field for farmers within the catchment area. The experiment which lasted for a period of two years commenced in 2012 and ended in 2014. This was done to demonstrate the influence of soil amendment on the yield and performance of two plantain groups that is, the False Horn and French Horn which are locally known as Apantu pa and Apem pa respectively. The area falls within latitude $7^{0}$ $03^{\prime} .631$ '”North and longitude $2^{0} 29^{\prime} .424^{\prime \prime}$ 'west.

The flour obtained from the plantain was subjected to laboratory analysis. The laboratory work investigated the influence of soil amendments on the flour that was prepared from the false horn plantain.

The experiment was set up in the Randomized Complete Block Design (RCBD) with three replications. 
Data were collected on samples at three (3) different laboratories. The laboratory of CSIR (Abuakwa), Department of Horticulture laboratory (KNUST) and the Food Research laboratory (Accra).

\section{Preparation and Application of Treatments}

The poultry manure was kept for period of three (3) months to allow decomposition and elimination of heat. The manure was applied (top dressing) to each stand with a planting distance of $2 \mathrm{~m}$ within rows and $3 \mathrm{~m}$ between rows. Each plot had a total plant population of fifteen (15) and occupied an area of $6 \times 8 \mathrm{~m}^{2}$.

Cocoa Pod Husk was subjected to open air drying for a period of three (3) months and it was further crushed in a sack using wooden pistils into smaller particles of about $2 \mathrm{~cm}$. Cocoa Pod Husk was also applied (top dressing) to each stand.

The land was divided into three blocks, with each block made up of six plots. Each plot received different soil amendment including the control (no treatment). The treatments administered on the various plots comprise $10 \mathrm{~kg} / \mathrm{stand}(16660 \mathrm{~kg} / \mathrm{h})$ of Poultry Manure(PM), $5 \mathrm{~kg}$ Poultry Manure and NPK $(0.065 \mathrm{~kg}+0.045 \mathrm{~kg}, 0.18 \mathrm{~kg}) / \mathrm{stand}$

$(108 \mathrm{kgN}+75 \mathrm{kgP}+300 \mathrm{kgK} / \mathrm{h}$ and $8330 \mathrm{~kg} / \mathrm{h} \mathrm{PM}), 10 \mathrm{~kg}$ Cocoa Pod Husk/stand (16660kg/h), 5kg cocoa pod husk and NPK $\quad(0.065 \mathrm{~kg}+0.045 \mathrm{~kg}, 0.18 \mathrm{~kg}) / \mathrm{stand}$ $(108 \mathrm{kgN}+75 \mathrm{kgP}+300 \mathrm{kgK} / \mathrm{h}$ and $8330 \mathrm{~kg} / \mathrm{h} \mathrm{CPH}), \mathrm{NPK}$ $(0.13 \mathrm{~kg}+0.09 \mathrm{~kg}, 0.36 \mathrm{~kg}) / \mathrm{stand} \quad(216 \mathrm{~kg} / \mathrm{h} \quad \mathrm{N}, 150 \mathrm{~kg} / \mathrm{h} \quad \mathrm{P}$, $600 \mathrm{~kg} / \mathrm{h} \mathrm{K})$.

\section{SAMPLE COLLECTION AND PREPARATION}

For the purpose of this study, the false horn variety (Apantu pa) was used due to its popularity in flour preparation. Fresh firm and matured but green plantain fruits were harvested from the various plots for use in the flour preparation. Following the recommendations of Baiyeri and Ortiz (2000). Finger samples were collected from the second hand of the proximal end of the bunch. The fruits were sliced to $5 \mathrm{~mm}$ diameter using a grater after they have been washed and peeled.

\section{Preparation of False Horn Plantain Flour}

Sliced plantain pulp were placed in an oven (WagtechModel GP120SSE300HYD) and dried at $60 \mathrm{oC}$ for 24 hours till it turned crispy. This was done by spreading out slices in layers of $1 \mathrm{~cm}$ thick on stainless-steel shelves in a tray-drying accessory of the oven. Dried slices were then cooled and milled in a hammer miller for three (3) times till a fine powder was obtained. Flour samples were packaged in high density polyethylene for laboratory analysis. At the laboratory, flour samples were screened through a sieve with $0.25 \mathrm{~mm}$ diameter of hole (Model BS 410) before the various analyses were carried out.

\section{Moisture}

Two grams $(2 \mathrm{~g})$ each of the samples were weighed in triplicates and dried for 24 hours at $60^{\circ} \mathrm{C}$ in an oven (Wagtech-Model GP120SSE300HYD) to a constant weight. Samples were removed, allowed to cool and weighed. The moisture content calculated and expressed as a percentage of the mass of sample taken by repeating the procedure of weighing and drying of each sample (AOAC 1990).

\section{Protein}

The Micro-Kjeldahl method of protein determination was used in the determination of the percentage of protein in the various sample (AOAC, 1990). Methods involved in the protein determination are two (2).

\section{Digestion}

Two grams $(2 \mathrm{~g})$ of sample was weighed unto a filter paper pre-folded like an envelope and introduced in to the kjeldhal flask in triplicates. Anti-bumping agents and half spoonful of selenium base catalyst were added. The flask was shaken to get the samples thoroughly wet immediately about $25 \mathrm{ml}$ of concentrated $\mathrm{H}_{2} \mathrm{SO}_{4}$ was added. The heater turned on when the flask was placed on the distillation rack and the sample digested until the solution became clear. Cooling of the flask was allowed at room temperature to obtain a clear solution. The digested sample was transferred into $100 \mathrm{ml}$ volumetric flasks and top up with distilled water to the $100 \mathrm{ml}$ mark.

\section{Distillation and Titration}

Two drops mixed indicator was added, when twenty-five of $2 \%$ boric acid was pipetted into a $250 \mathrm{ml}$ Erlenmeyer flask followed by $18 \mathrm{ml}$ of $40 \% \mathrm{NaOH}$. The conical flask and its contents was placed under the condenser in a position that left the tip of the condenser completely submerged in the solution. The digested sample of ten millilitres $(10 \mathrm{ml})$ was poured into the steam jacket. The stopcock was closed to drive the liberated ammonia gas directly in to the collection flask and steam forced from the decomposition chamber by shutting the stop cock on the steam tap outlet. Distillation continued until the boric acid turned bluish green, before distillation was stop. The distillate titrated against $0.1 \mathrm{~N} \mathrm{H}_{2} \mathrm{SO}_{4}$ to a faint pink endpoint and the set up was then disconnected afterwards. Similar method was used to prepare a blank in which a similar piece of filter paper minus sample was used. The percentage nitrogen was multiply by the appropriate conversion factor of 6.25 to obtain the percentage protein.

\section{Starch Determination}

The Starch content was obtained by adopting the method of Lintner but with slight modification. Triturate $2.5 \mathrm{~g}$ of flour with $20 \mathrm{ml}$ of water, and $40 \mathrm{ml}$ hydrochloric acid (sp.gr.1.15) added in small portions. Wash the mixture into a $200 \mathrm{ml}$ flask with hydrocholic acid $(12 \% \mathrm{w} / \mathrm{w} \mathrm{HCL})$ add $10 \mathrm{ml}$ of $5 \%$ phosphotungstic acid to precipitate proteins and make the volume up to $200 \mathrm{ml}$ with $12 \%$ hydrochloric acid. Shake, filter and measure the optical 
rotation of the filtrate in a $200-\mathrm{mm}$ tube. Multiply the reading by 1.912 to get the percentage of starch directly.

\section{Pasting Characteristics}

American Association of Cereal Chemist Approved Method 22.10 (AACC, 1983) with slight modifications was used to determine the pasting characteristics of plantain flour samples which were in triplicates (moisture content ranging between 7.5 and 13.65 and corrected to 14\%). A Brabenderviscoamylograph (Viscograph PT100) from Food Research Institute, Accra was used to study all the pasting properties of the flour at $75 \mathrm{rpm}$ and a torque of $700 \mathrm{~g}$ equivalent to 100 Brabender units (BU) (Demiateet al., 2001). Under a constant stirring speed, the slurry was heated from $25-95^{\circ} \mathrm{C}$ at a uniform rate of $1.5^{\circ} \mathrm{C} / \mathrm{min}$. Monitoring was continuously done on the torgue. Cooling took place under a controlled rate of $1.5 \mathrm{C} / \mathrm{min}$ (Damardjati and Luh 1987) to $50^{\circ} \mathrm{C}$ after torgue was formed. The cooked paste viscosity of $14 \%$ slurries in $420 \mathrm{ml}$ water was measured. Pasting parameters including beginning of gelatinization, maximum/peak viscosity, end of final holding, break down and set back were recorded and expressed as Brabender Units (BU) (Demiateet al., 2001).

\section{Swelling Power and Solubility}

Based on a slight modification of the method of Appiah et al. (2011) solubility and swelling power were determined. One $(1 \mathrm{~g})$ of flour was transferred into a $50 \mathrm{ml}$ capacity graduated centrifuge tube. A total volume of $40 \mathrm{ml}$ was obtained by adding deionized water. In other to avoid fragmentation of starch granules, the suspension was stirred just sufficiently and uniformly avoiding excessive speed. The sample in the centrifuge tube was heated at $85^{\circ} \mathrm{C}$ in a thermostatically controlled temperature water bath (Grant type) for $30 \mathrm{~min}$ with constant stirring. The tube was cooled to room temperature after it had been removed and wiped dry. It was centrifuged for $15 \mathrm{~min}$ at $2200 \mathrm{rpm}$. The supernatant was evaporated and the residue weighed to ascertain the solubility. The sediment paste was weighed and the percentages of swelling power and solubility were then calculated. Determinations were done in triplicate.

\section{Water and Oil Absorption Capacities}

With slight modification of the method of Appiah et al. (2011), water absorption capacity was ascertained. $1.0 \mathrm{~g}$ of the sample in a beaker was top up with $10 \mathrm{~mL}$ of distilled. A Rota mixer 7023 was used for missing the suspension for $3 \mathrm{~min}$. The supernatant obtained was measured in a $10 \mathrm{~mL}$ graduated cylinder by centrifuging the suspension at $5000 \mathrm{rpm}$ for $30 \mathrm{~min}$. The density of water was taken as $1.0 \mathrm{~g} / \mathrm{ml}$. The difference between the initial volume of water added to the sample and the volume of the supernatant was used to calculate the water absorbed.
The same methodology was adopted for oil absorption except that oil was used instead of water. The density of the oil used was $0.9095 \mathrm{~g} / \mathrm{ml}$.

The volume of water or oil on the sediment was measured. Oil and Water absorption capacities were calculated in millilitres of oil or water absorbed per gram of flour respectively.

\section{Bulk Density}

Water absorption capacity was determined using the method of Appiah et al. (2011). 50.0g of the flour sample was weighed into a $100 \mathrm{ml}$ graduated measuring cylinder. The cylinder was then gently tapped repeatedly on the laboratory bench till a constant volume was obtained. The volume was then noted.

The bulk density $\left(\mathrm{g} / \mathrm{cm}^{3}\right)$ was calculated as weight of flour (g) divided by flour volume $\left(\mathrm{cm}^{3}\right)$.

That is Bulk density $\left(\mathrm{g} / \mathrm{cm}^{3}\right)=$ weight of sample $(\mathrm{g})$ /volume of sample after tapping $\mathrm{cm}^{3}$.

\section{RESULTS AND DISCUSSION QUALITY CHARACTERISTICS OF PLANTAIN FLOUR}

\section{Moisture Content}

There were significant differences $(\mathrm{P} \leq 0.01)$ in the moisture content of the plantain flour among the various amended soils. Flour produced from plantain without any soil amendment (control) recorded the highest moisture content $(12.08 \%)$, significantly different from the other amendments except NPK+CPH amendment soil. Flour produced from plantain with $\mathrm{CPH}$ amended soil recorded the lowest moisture content $(8.41 \%)$.

Ishmael et al., (2011) and Onwuka and Onwuka, (2005) however, reported moisture contents of $61.10 \%$ and $61.6 \%$, respectively which were comparatively higher than the findings in the present study. The lower pulp moisture content found in this study is an indication of the higher dry matter content of the pulp which is known to have an influence on the energy content due to the high carbohydrate content associated with high dry matter (Gowen, 1995). The moisture content of the flour was within the recommended range of $10 \%$ to $14 \%$ for flours (Akubor and Badifu, 2004). Appiah et al. (2011) reported moisture content of $8.53 \%$ to $9.11 \%$ for flours obtained from breadfruit cultivars which were slightly lower than what pertained in the current study.

Higher moisture content in flours have been reported to enhance spoilage through creating favourable condition for microbial proliferation as well as enhance enzymatic deterioration (Oduroet al., 2009). Since the flours in the present study had acceptable moisture content they are expected to have longer shelf life.

\section{Protein content}

There were also significant differences $(\mathrm{P} \leq 0.01)$ in the plantain flour protein between the various amended soils. 
Flour produced from plantain with NPK amendment recorded the highest protein content $(5.27 \%)$, significantly different from the flours from NPK+PM amendment and the control which recorded the lowest protein contents of 3.39 and 3.44, respectively (Table 1). All the other amendments produced flours with protein content similar to that from the NPK amended soil.

This could be due to the readily availability of nitrogen and phosphorus needed for protein synthesis from the NPK as against the slow release of these same elements by the organic amendments. In the present study, the protein in the flour recorded from soils amended with NPK was higher than those quoted by previous researchers such as Ishmael (2011) $(3.06 \%)$ and Onwuka and Onwuka (2005) (2.8\%). The differences could be due to the type of fertilizer applied and the condition of the soils used for the plantain cultivation. In spite of these differences, the protein content of false horn plantain flour was generally low and as such required fortification with other high protein foods to boost the nutritional content of the flour as indicated by Zhao et al. (2004).

\section{Starch Content}

For starch content, flour produced from plantain without any soil amendment recorded the highest (51.33\%), significantly different from all the other amendments (Table 1). Flour produced from plantain with NPK+PM amended soil recorded the lowest starch content $(30.67$ $\%$ ) although similar to those from $\mathrm{NPK}+\mathrm{CPH}$ and $\mathrm{PM}$ amended soils.

From the present study, the findings are indicative that the flour starch is not influenced by any soil amendments. Starch characteristics such as swelling power, solubility pattern, pasting behaviour are important for improved quality of food products and could be useful for the development of composite blends from small scale industrial level as value-added products (Ikegwuet al., 2010).

\begin{tabular}{lll}
\multicolumn{3}{c}{ Table. 1 : Effect of soil amendments on protein and starch content of plantain flour } \\
\hline Treatment & Protein $(\%)$ & Starch $(\%)$ \\
\hline NPK & 5.27 & 40.33 \\
PM & 4.41 & 36.67 \\
CPH & 3.53 & 41.33 \\
NPK+PM & 3.39 & 30.67 \\
NPK+CPH & 3.76 & 32.00 \\
CONTROL & 3.44 & 51.33 \\
\hline LSD $(0.01)$ & 1.779 & 8.857 \\
CV & 17.99 & 9.17 \\
\hline
\end{tabular}

\section{FUNCTIONAL PROPERTIES OF FALSE HORN PLANTAIN FLOUR}

There were no significant differences $(\mathrm{P} \geq 0.01)$ between the soil amendments with regards to the functional properties of the plantain flour. The functional properties assessed were bulk density, oil absorption capacity, water absorption capacity, solubility and swelling power. Bulk density ranged from $0.79 \mathrm{~g} / \mathrm{cm}^{3}$ to $0.84 \mathrm{~g} / \mathrm{cm}^{3}$. Oil absorption capacity ranged from $1.82 \mathrm{ml} / \mathrm{g}$ to $10.73 \mathrm{ml} / \mathrm{g}$ whereas water absorption capacity ranged from $1.37 \mathrm{ml} / \mathrm{g}$ to $2.05 \mathrm{ml} / \mathrm{g}$. Solubility power ranged from $7.77 \%$ to $9.96 \%$ whiles swelling power ranged from $9.49 \%$ to $10.45 \%$.

\section{Bulk Density of Plantain Flours}

There were no significant differences $(\mathrm{P}>0.01)$ between the various soil amendments with regards to the bulk density of the flour. The bulk densities ranged from $0.79 \mathrm{~g} / \mathrm{cm}^{3}$ to $0.84 \mathrm{~g} / \mathrm{cm}^{3}$ with soil amended with PM recording $0.84 \mathrm{~g} / \mathrm{cm}^{3}$ and $\mathrm{NPK}+\mathrm{PM}$ recording $0.79 \mathrm{~g} / \mathrm{cm}^{3}$. Ismael et al., (2011) recorded a bulk density of $0.63 \mathrm{~g} / \mathrm{cm}^{3}$ for false horn. The disparities in the values could be due to an interplay of several factors, such as environmental conditions during production, the fertility status of the soil and the method of processing the plantain into flour. Comparatively, the bulk density of fermented maize flour was reported to be $0.55 \mathrm{~g} / \mathrm{cm}^{3}$ (Akubor and Badifu, 2004 and Mbataet al., 2009). According to Bhattacharya and Prakash (1994), the bulk density of foods increases with increasing starch content. Furthermore, Okezie and Bello (1988)

stressed that high bulk density of food material is important in relation to its packaging. Ijarotimi and Ashipa (2005) documented that, higher bulk density is essential in the since that it offers greater packaging advantage as greater quantity of flour may be packed within a constant volume. Oladele and Aina (2007) also describe bulk density as the measure of the heaviness of a flour sample. Mbataet al., (2009) indicated that weaning food should have low water absorption capacity and low bulk density in order to produce a more suitable and nutritious weaning food. Consequently, the flour produced from plantain with NPK+PM amendment might be suitable for preparing weaning food formulations.

Water Absorption Capacity of Plantain Flours Water absorption capacity (WAC) for false horn plantain flour varied from $1.37 \mathrm{ml} / \mathrm{g}$ to $2.05 \mathrm{ml} / \mathrm{g}$. Flours obtained from plantain grown on soils without any amendment 
(control) recorded $2.05 \mathrm{ml} / \mathrm{g}$ for WAC whiles flour from $\mathrm{CPH}$ amendment recorded the lowest WAC value of 1.37. Elmoneimet al. (2005) indicated that water absorption capacity gave an indication of the amount of water available for gelatinization. Low water absorption capacity is desirable for making thinner gruels. Desikachar (1980) indicated that a high water absorption capacity of flours increases its viscosity (consistency) when mixed with water, resulting in a thick paste but does not allow free-flow of the meal (Mosha and Lorri 1987).

Oil Absorption Capacity of False Horn Plantain Flour False horn plantain flours had oil absorption capacity $(\mathrm{OAC})$ ranging from $10.72 \mathrm{~g} / \mathrm{g}$ to $1.82 \mathrm{~g} / \mathrm{g}$. Flour produced from plantain on soil amended with $\mathrm{NPK}+\mathrm{CPH}$ recorded the oil absorption capacity of $10.72 \mathrm{~g}$ whereas flour from plantain with $\mathrm{CPH}$ amendment recorded oil absorption capacity of $1.82 \mathrm{~g}$. The oil absorption capacity values recorded in the present study were higher than the $1.30 \mathrm{~g} / \mathrm{g}$ recorded by Mepbaet al., (2007). The variation could be due to the varietal differences of plantain used as well as the stage of maturity of the fruits harvested. In a study on breadfruit flour, an oil absorption capacity range of $0.38 \mathrm{~g} / \mathrm{g}$ to $1.13 \mathrm{~g} / \mathrm{g}$ was obtained (Appiah et al., 2011). Also, Udensi and Okoronkwo (2006) reported oil absorption capacity value of $2.2 \mathrm{~g} / \mathrm{g}$ for mucunabean. Generally, flours with lower oil absorption capacity have higher flavor retention abilities (Oladele and Aina, 2007). Consequently, flours from plantain with $\mathrm{CPH}$ amendment could have a high potential of retaining flavour and therefore could be desirable in food product formulation. Adejuyitanet al., (2009) explained that the lower oil absorption capacity could be due to low hydrophobic proteins which show superior binding of lipids. For flours with high oil absorption capacities, such as that observed in the flour from plantain with $\mathrm{NPK}+\mathrm{CPH}$ amendment, they could be useful in food formulation where oil holding capacity is needed for instance in the sausage making, soups and cakes (Aremuet al., 2006).

\section{Swelling Power of False Horn Plantain}

Swelling power of false horn plantain flour ranges from 10.45 to 9.49. Ishmealet al., (2011) documented similar swelling power values (7.14 to 10.28) for false horn plantain flour. The swelling power values of plantain flour are comparable to those for soybean-fortified yam flour (6.8-9.6) (Jimo and Olatidoye, 2009). However, plantain flour exhibited a better swelling capacity than cassava and this could be due to the small particle sized plantain starch which is highly digestible in nature (Ojinnakaet al., 2009).

In comparison to the flour of other crops, there appeared to be no consistent trend as in some cases the swelling power values are lower (tigernut - 2.47, Oladele and Aina 2007); breadfruits cultivars - 4.84 to 6.23 (Appiah et al., 2011) whiles in other cases the values are higher (cereal starches - 24 to 42 (Tester and Morrison, 1990). The swelling power test provided a suitable predictive method for identifying flours capable of producing high quality noodles( McComicket al., 1991). The false horn plantain flours in the present study had lower swelling power values and as such might not be suitable for noodle production.

Also in the present study, solubility percentage strongly affected the swelling power of the plantain flour, an indication that as the solubility of the flour increased the swelling power also increased leading to an improved water absorption capacity of the flour (Etudaiyeet al., 2009). Johnson et al. (2001) indicated that higher solubility also permitted better digestibility.

\section{EFFECTS OF SOIL AMENDMENTS ON THE PASTING PROPERTIES OF DERIVED PLANTAIN FLOUR}

\section{Gelatinization Temperature}

There were significant differences $(\mathrm{P} \leq 0.01)$ between flours produced from the various amended soils with regards to temperature at the beginning of gelatinization (Table 2). Flours produced from plantain with NPK+PM amendment and the Control recorded the highest temperature at the beginning of gelatinization $\left(77.47^{\circ} \mathrm{C}\right.$ and $77.45^{\circ} \mathrm{C}$ respectively), which differed significantly from flours produced from PM amended soils which recorded the least temperature $\left(75.45^{\circ} \mathrm{C}\right)$. However, the temperature figure obtained from flours produced by PM amended soils was not significantly different from NPK, $\mathrm{CPH}$, and $\mathrm{NPK}+\mathrm{CPH}$ which recorded temperatures of $77.22^{\circ} \mathrm{C}, 76.73^{\circ} \mathrm{C}$ and $77.10^{\circ} \mathrm{C}$ respectively.

\section{Time Taken to Reach Peak Viscosity}

There were significant differences $(\mathrm{P} \leq 0.01)$ between the flours produced from the various amended soils with regards to the time taken to reach peak viscosity (Table 2). Flours produced from soils amended with $\mathrm{NPK}+\mathrm{CPH}$ and the control recorded the highest time taken to reach peak viscosity $(1912.50$ sec. and $1881.70 \mathrm{sec}$. respectively), which was significantly different from flours obtained from NPK amended soils which recorded the least time (1065.00 sec.).

\section{Beginning of Gelatinization Time}

There were significant differences $(\mathrm{P} \leq 0.01)$ between the flours produced from plantain grown on the various amended soils with regards to the time taken for the beginning of gelatinization. Flours produced from plantain grown on NPK+PM amended soil $(1150.00 \mathrm{sec})$ and the control $(1150.80 \mathrm{sec}$.) recorded the highest time for 'Beginning of gelatinization' which were significantly different from PM which recorded the least time (1065.00 sec.) (Table 2). The time recorded by flour produced from PM amended soils was not significantly different from $\mathrm{NPK}, \mathrm{NPK}+\mathrm{CPH}$, and $\mathrm{CPH}$ which recorded time of $1141.70 \mathrm{sec} ., 1137.50 \mathrm{sec}$. and $1125 \mathrm{sec} .$, respectively. 
Table.2: Effect of soil amendment on beginning of gelatinization temperature, timeand time taken to reach peak viscosity offalse horn plantain flour

\begin{tabular}{llll}
\hline Treatment & $\begin{array}{l}\text { Beginning of gelatinization } \\
\text { temperature }\left({ }^{\circ} \mathrm{C}\right)\end{array}$ & $\begin{array}{l}\text { Beginning of gelatinization } \\
\text { time }(\mathrm{sec} .)\end{array}$ & $\begin{array}{l}\text { Time taken to Reach Peak } \\
\text { Viscosity }(\mathrm{sec} .)\end{array}$ \\
\hline NPK & 77.22 & 1141.70 & 1675.80 \\
PM & 75.45 & 1065.00 & 1811.70 \\
$\mathrm{CPH}$ & 76.73 & 1125.00 & 1791.70 \\
NPK+PM & 77.47 & 1150.00 & 1859.20 \\
NPK+CPH & 77.10 & 1137.50 & 1912.50 \\
CONT. & 77.45 & 1150.80 & 1881.70 \\
\hline LSD $(0.01)$ & 1.829 & 77.072 & 77.072 \\
CV & 1.50 & 4.30 & 0.85 \\
\hline
\end{tabular}

Higher gelatinization temperatures $\left(81.87^{\circ} \mathrm{C} ; 94.6^{\circ} \mathrm{C}\right)$ have been reported for breadfruit flours by Appiah et al., (2011) and by Oladele and Aina (2007) from other studies. Mira et al. (2005), explained that such higher gelatinization temperatures could be the result of delayed or restricted swelling and amylose leaching. Lower gelatinization temperature, on the other hand, is indicative of lower cooking temperature and shorter cooking time (Otegbayoet al., 2006). Appiah et al., (2011) reported that, flours with shorter cooking time is advantageous as it might reduce energy consumption (fuel) as well as reduce the cost and time of processing. From the present study therefore, flour from plantain with PM amendment is more likely to cook faster than the flour from the plantain with NPK+PM amendment.

Viscosities (Maximum, Final, Breakdown and Setback)

Flours from plantain with $\mathrm{CPH}$ amendment recorded the highest maximum viscosity (401.33BU) whereas flours from plantain with NPK amendment recorded the least viscosity of 354.33BU. Zakpaaet al., (2010) reported a maximum viscosity of $677 \mathrm{BU}$ for false horn plantain flour which is higher than the value in the present study. Also in an earlier study, maximum viscosities have been reported for Potato (3000 BU), Maize (77.5 BU), Wheat (300 BU) and Cassava (966 BU) (Ciaccoet al., 1997). The differences in values could be attributed to pasting characteristics which depend on granule size and amylose content. Larger granules have a lower surface area to volume ratio and therefore the association between hydrogen bond and granules are very weak, hence increased swelling (Zakpaaet al., 2010). Maximum viscosity is an important feature of starch flour since it gives an indication of the ability of the flour to form a thick paste during cooking which is the result of the swelling power of the starch (Adebowaleet al., 2005; Opataet al., 2007). Kim et al., (1995) indicated that starch with high viscosity is desirable as thickening agents in industry and in food systems.

\section{Breakdown Viscosity}

The breakdown values for false horn plantain flour ranged between 51.00 BU $(\mathrm{NPK}+\mathrm{CPH})$ to $93.00 \mathrm{BU}(\mathrm{NPK})$ in the present study (table 3 ). The breakdown values generally indicate the difference between peak viscosity and minimum viscosity and show the degree of drop during heating and the extent of starch granule disintegration (Adebowaleet al., 2005). Higher breakdown in viscosity suggests lower ability of sample to withstand heating and shear stress during cooking. Therefore, starch samples with lower breakdown will have better ability to withstand heating and shear stress giving more stable cooked paste (Zobel, 1984). From the present study therefore, flours from plantain with $\mathrm{NPK}+\mathrm{CPH}$ amendment would form a more stable paste.

\begin{tabular}{lll}
\multicolumn{2}{c}{ Table.3: Effect of soil amendment on breakdown and setback of false horn plantain flour } \\
\hline Treatment & $\begin{array}{l}\text { Breakdown viscosity } \\
(B U)\end{array}$ & Setback viscosity (BU) \\
\hline NPK & 93.00 & 7.50 \\
PM & 79.00 & -93.17 \\
CPH & 90.33 & -14.83 \\
NPK+PM & 82.67 & -70.67 \\
NPK+CPH & 51.00 & -86.83 \\
CONT. & 71.17 & 35.83 \\
\hline LSD $(0.01)$ & 18.646 & 76.249 \\
CV & 15.08 & 129.70 \\
\hline
\end{tabular}




\section{Start of Cooling and End of Cooling}

There were significant differences $(\mathrm{P} \leq 0.01)$ in start of cooling viscosity between the flours produced from plantain under the various soil amendments (Table 4). All the amendments and the control recorded significantly higher start of cooling viscosity values than that from the NPK amendment which recorded the least start of cooling viscosity value (Table 4$)$. The end of cooling viscosity values also differed significantly $(\mathrm{P} \leq 0.01)$ between the flours produced from plantain under the various soil amendments (Table 4). Flour produced from plantain without amendment (control) recorded the highest viscosity at the end of cooling, significantly different from flour from NPK+PM and PM amendments.

Table.4: Effect of soil amendment on start of cooling and end of cooling on false horn plantain flour

\begin{tabular}{lll}
\hline Treatment & $\begin{array}{l}\text { Start of cooling viscosity } \\
\text { (BU) }\end{array}$ & $\begin{array}{l}\text { End of cooling viscosity } \\
\text { (BU) }\end{array}$ \\
\hline NPK & 261.33 & 268.67 \\
PM & 303.00 & 210.00 \\
CPH & 311.00 & 295.83 \\
NPK+PM & 309.50 & 238.83 \\
NPK+CPH & 317.67 & 255.00 \\
CONT. & 303.00 & 331.00 \\
\hline LSD $(0.01)$ & 23.083 & 87.808 \\
CV & 4.83 & 20.75 \\
\hline
\end{tabular}

\section{Start of Holding and End of holding}

There were significant differences $(\mathrm{P} \leq 0.01)$ between the flours from the various amended soils with regards to the viscosity at the start of holding (Table 5). Flour produced from plantain amended with $\mathrm{CPH}$ recorded significantly higher start of holding viscosity values than the other amendments except that from the NPK + PM amended soil (Table 5). The least start of holding viscosity was recorded by NPK amended soil.

Table.5: Effect of soil amendment on start of holding and end of final holding on false horn plantain flour

\begin{tabular}{lll}
\hline Treatment & $\begin{array}{l}\text { Start of holding viscosity } \\
(\mathrm{BU})\end{array}$ & $\begin{array}{l}\text { End of final holding } \\
\text { viscosity (BU) }\end{array}$ \\
\hline NPK & 349.50 & 227.50 \\
PM & 378.00 & 182.33 \\
CPH & 399.67 & 263.33 \\
NPK+PM & 387.00 & 213.17 \\
NPK+CPH & 359.00 & 198.00 \\
CONT. & 360.00 & 303.83 \\
\hline LSD $(0.01)$ & 14.777 & 67.626 \\
CV & 2.50 & 18.41 \\
\hline
\end{tabular}

\section{REGRESSION RELATIONSHIPS BETWEEN SOME AGRONOMIC PARAMETERS, FUNCTIONAL AND PROXIMATE PROPERTIES OF PLANTAIN FLOUR}

There was a significant relationship between the swelling power of plantain flour and its solubility. The swelling power of the flour was positively affected by the flour's solubility. Solubility of the flour accounted for $88 \%$ of the variation in the observed swelling power (Eqn 1).

Swelling Power $=7.08157+0.29512($ solubility $\%) ; R^{2}$ $=0.88 ; \mathrm{p}=0.018 ; \mathrm{n}=10($ Eqn 1$)$.
The end of holding viscosity values also differed significantly $(\mathrm{P} \leq 0.01)$ between the flours produced from plantain under the various soil amendments (Table 5). Flour produced from plantain without soil amendment (control) recorded the highest viscosity at the end of holding, which was not significantly different from flour from $\mathrm{CPH}$ amended soils. 
affected by the fruit pulp weight such that $70 \%$ of the variation in the starch content of the flour was explained by the fruit pulp weight (Eqn 3).

Starch Content $=27.8127+3.76498$ (pulp weight); $\mathbf{R}^{2}$ $=0.70 ; p=0.046 ; n=10($ Eqn 3$)$.

There was a significant relationship between the maximum viscosity of the flour and the oil absorption capacity of the flour. The maximum viscosity of the flour was positively and significantly affected by the oil absorption capacity of the flour. However, only $25 \%$ of the variation in the maximum viscosity of the flour was explained by the oil absorption capacity of the flour (Eqn 4).

$\mathrm{Y}(\max$. viscosity $)=372.501+1.33796($ oil absorption $)$; $R^{2}=0.25 ; p=0.035 ; n=10 .($ Eqn 4$)$.

There was also a significant relationship between the maximum viscosity of the flour and the starch content of the flour. The maximum viscosity of the flour was positively and significantly affected by the starch content of the flour. However, only $26 \%$ of the variation in the maximum viscosity of the flour was explained by the starch content of the flour. (Eqn 5).

$Y(\max$. viscosity $)=423.169-1.19374($ starch $) ; R^{2}=$ $0.26 ; p=0.030 ; n=10$. (Eqn 5).

\section{CONCLUSION}

Flours from plantain obtained from amended soils recorded moisture contents which were within the acceptable levels for flours. The flour with the lowest moisture content was produced from plantain with $\mathrm{CPH}$ amendment. The protein content of false horn plantain flour was, however, lower and as such required fortification with other high protein foods to boost the nutritional content of the flour.

The starch from plantain flour was not influenced by any of the soil amendments. On the other hand, flour produced from plantain onsoil amended with NPK+PM had low bulk density and low water absorption capacity and therefore might be suitable for preparing weaning food formulations. Contrarily, the false horn plantain flours had lower swelling power values and as such might not be suitable for noodle production.

Flours from plantain with $\mathrm{CPH}$ amended soil had lower oil absorption capacity which suggested that it would have a high potential of retaining flavour and therefore could be desirable in food product formulations. Similarly, flour from plantain with PM amendment was more likely to cook faster than the flour from the plantain with the other soil amendments. Flours from plantain with $\mathrm{NPK}+\mathrm{CPH}$ soil amendment would form a more stable paste because of its lower breakdown value which will ensure its ability to withstand heating and shear stress and give more stable cooked paste.

Generally, the Plantain flour compared favourably with known food flours and therefore could be applicable as thickening agents and also find usefulness in fufu powder preparation and baking.

\section{RECOMMENDATIONS}

1. Further studies could be done with other combinations of organic and inorganic fertilizers.

2. Soils amended with cocoa pod husk, poultry manure, NPK fertilizer and their combinations could be adopted as it is effective in enhancing the quality of plantain flour.

3. Sensory studies (texture, colour, and aroma) need to be conducted on the plantain flours emanating from the amended soils.

\section{REFERENCES}

[1] AACC, (1983). American Association of Cereal Chemist 10 edition Approved Methods of Analysis

[2] Adebowale, K. O., Olu-Owolabi, B. I., Olawumi, E. K. and Lawal, O. S. (2005). Functional properties of native, physically and chemically modified breadfruit (Artocarpusaltilis) starch. Industrial Crop Production, 21, 343-351.

[3] Adejuyitan, J. A., Otunola, E. T., Akande, E. A., Bolarinwa, I. F. and Oladokun, F. M. (2009). Some physicochemical properties of flour obtained from fermentation of tigernut (Cyperusesculentus) sourced from a market in Ogbomoso, Nigeria. African Journal of Food Science. Vol 3(2): 51-055.

[4] Adeniji, T.A., Barimalaa, I.S. and Achinewhu, S.C. (2006). Evaluation of bunch characteristics and flour yield potential in black Sigatoka resistant plantain and banana hybrids. Glob. J. Pure Appl. Sci. (NGA) 12: 41-43

[5] Adeniji, T.A and Empere, C.E. (2001). The development, production and quality evaluation of cake made from cooking banana flour. Global Journal of Pure and Applied Sciences; 7(4): 633635

[6] Akubor, P. I. and Badifu, G. I. O. (2004). Chemical composition, functional properties and baking potential of African breadfruit kernel and wheat flour blends. International Journal of Food Science and Technology 39: 223-229. 2476.

[7] AOAC (1990). Official Methods of Analysis. Association of Official Analytical Chemists $15^{\text {th }}$ Edition, Washington D.C.

[8] Appiah, F., Oduro, I. and Ellis, W. O. (2011a). Pasting properties of Treculiaafricana seed flour in Ghana and the production of a breakfast meal. 
Agriculture and Biology Journal of North America 2(2): 325-329

[9] Aremu, M. O., Olonisakin, A; Atolaye, B. O and Ogbu, C. F. (2006). Some nutritional and functional studies of Prosopisafricana. Electronic Journal of Environmental, Agricultural and Food Chemistry 5(6): 1640-1648

[10] Ayodele, O.H. and V.G. Erema, (2011). Glycemic indices of processed unripe plantain meals. Afr. J. Fd. Sci., 4: 514-521.

[11] Baiyeri, K P. and Tenkouano, A. (2007). Manure placement influenced growth and dry matter yield of a plantain hybrid. African Crop science conference Proceedings, 8: 385-390.

[12] Baiyeri K.P and. Ortiz, R. (2000). Agronomic evaluation of plantain and other triploid Musa. In K. Craenen, R. Ortiz, E.B.Karamura, and D.R. Vuylsteke (eds.). Proceeding of First 116 International Conference of Banana and plantain in Africa, Kampala, Uganda, 12-18 October, 1996. International Society for Horticulture, 540: 125-135

[13] Bhattacharya, S., \& Prakash, M. (1994). Extrusion of blends of rice and chick pea flours: A response surface analysis. Journal of Food Engineering, 21(3), 315-330.

[14] Ciacco CF, D'Appolonia, BL (1997).Characterisation of starches from various tubers and their use in bread making, Cereal Chem., 54:1096-1107.

[15] Damardjati, D. S. and Luh, B. S. (1987). Physicochemical properties of Extrusion-cooked rice breakfast cereals. Proceeding of the 7th World Congress of Food Science and Technology. Trends in Food Processing 1: Membrane Filtration Technology and Thermal Processing and Quality of Foods. Singapore. October. A. A. Ghee et al (Eds.). pp. 251-264

[16] Damirel, D. and Turhan, M. (2003), Air-drying behavior of Dwarf Cavendish and Gros Michel banana slices. Journal of food engineering, 63, 349359

[17]Dankyi A. A., Banful B., Anno-Nyako F. O., Dzomeku B. M., Asafu-Agyei J. N. and Haleegoah J. (2007). Post-harvest handling, processing, marketing trends and routes of plantains and bananas in Ghana (final report)

[18] Demiate, I.M., Oetterer, M. and Wosiacki, G. (2001): Characterization of chestnut (casteneasativa, Mill) starch for Industrial Utilization. Brazilan Archives of Biology and Technology 44:1

[19] Desikachar, H. S. R. (1980). Development of weaning foods with high caloric density and low hot-paste viscosity using traditional technologies. Food and nutrition bulletin, 2(4), 2123.

[20] Elmoneim, A., Elkhalifa, O., Schiffler, B. and Bernhardt, R. (2005). Effect of fermentation on the functional properties of sorghum flour. Food Chemistry 92: 1-5.

[21] Etudaiye, H. A., Nwabueze, T. U. and Sanni, L. O. (2009). Pasting and functional properties of processed cassava from mosaic disease-resistant vaieties cultivated in a high rainfall zone.Nigeria Food Journal 27 (2): 185-193

[22] Gowen, S. R. (1995). Pests. In Bananas and plantains (pp. 382-402). Springer Netherlands

[23] Ikegwu, O. J., Okechikwu, P. E. and Ekumankana, E. O. (2010).Physico-Chemical and Pasting Characteristics of Flour and Starch from Achi BrachystegiaeurycomaSeed. Journal of Food Technology 8(2): 58-66.

[24] Ijarotimi, O. S. and Ashipa, F. (2005). Chemical composition, sensory and physical property of home processed weaning food based on low cost locally available food materials (1). International Journal of Molecular and Advance Sciences 1 (3): 213-219.

[25] Ishmael, A. (2011). Drying Characteristics of Pretreated Pulp of Triploid and Tetraploid Plantain Varieties (Doctoral dissertation).

[26] Jimoh, K. O. and Olatidoye, O. P. (2009). Evaluation of physicochemical and rheological characteristics of soybean fortified yam flour. Journal of Applied Biosciences 13: 703 - 706.

[27] Johnson, A., Aderele, W. I., Osinusi, K. O., Gbadero, D. A. (2001). Effect of malting and traditional heat processing on paste viscosity. African Journals Online, Nigerian Journal of Paediatrics. 28(4): 119-127

[28] Kim, Y. S., Wiesenborn, D. P., Orr, P. H., and Grant, L. A. (1995). Screening potato starch for novel properties using differential scanning calorimetry. Journal of Food Science 60: 1060-1065

[29] Kipkosgei, L.K., Akundabwen, L.S.M and Hutchinson, M.J. (2003). The effect of farmyard manure and nitrogen fertilizer on vegetative growth, leaf yield and quality attributes of Solanumvillosum (Black nightshade) in Keiyo district, rift valley. African Crop Science Conference Proceedings, Vol. 6. 514-518.

[30] Lahav, E. (1995). Banana nutrition (pp. 258-316). Springer Netherlands

[31] Matil, K.F. (1971). Functional requirements of proteins for foods. Am. Oil Chem. Soc., 48, 477480.

[32] Mbata, T. I., Ikenebomeh, M. J. and Ezeibe, S. (2009). Evaluation of mineral content and functional properties of fermented maize (Generic and specific) 
flour blended with bambara groundnut (Vigna subterranean L). African Journal of Food Science 3(4): 107-112

[33] Mepba, H. D., Eboh, L., \&Nwaojigwa, S. U. (2007). Chemical composition, functional and baking properties of wheat-plantain composite flours

[34] McComick, K. M., Panozzo, J. F. and Hong, S. H. (1991). A swelling power test for selecting potential noodle quality wheats. Australian Journal of Agricultural Research 42 (3): 317-323

[35] Mira, I., Eliasson, A. C. and Person, K. (2005). Effect of surfactant structure on the pasting properties of wheat flour and starch suspensions. Cereal Chemistry 62: 44-52.

[36] MoFA SRID, 2014, Ministry of food and agriculture, statistics research and information directorate, National Crop production estimates 2010-2013

[37] Mosha, A. C., \&Lorri, W. S. (1987). High-nutrient density weaning foods from germinated cereals.

[38] Munoz, G.R., Kelling, K.A., Powell, J.M. and Speth, P.E. 2004. Comparison of estimates of first year dairy manure nitrogen availability or recovery using nitrogen-15 and other techniques. J. Environ. Qual. 33:719-727.

[39] Ndukwe, O. O., Muoneke, C. O., Baiyeri, K. P., \&Tenkouano, A. (2014). Effect of organic and inorganic fertilizers on nutrient concentrations in plantain (Musa spp.) fruit pulp. African Journal of Biotechnology, 11(7), 1651-1658.

[40] Oduro, I., Ellis, W. O., Aryeetey, S. K., Ahenkora, K. and Otoo, J. A. (2000). Pasting characteristics of starch from new varieties of sweet potato. Tropical Science 40: 25-28.

[41] Okezie, B.O. and A.B. Bello, (1988). Physicochemical and functional properties of winged bean flour and isolate compared with soy isolate.J. Food Sci., 53: 450-454.

[42] Ojinnaka, M.C., Akobundu E.N.T. and Iwe, M.O. (2009) Cocoyam Starch Modification Effects on functional, Sensory and Cookies Qualities. Pakistan Journal of Nutrition 8 (5): 558-567.

[43] Oladele, A. K. and Aina, J. O. (2007). Chemical composition and functional properties of flour produced from two varieties of tigernut (Cyperusesculentus) African Journal of Biotechnology 6 (21): 2473-2476

[44] Onwuka G.I. And Onwuka N.D. (2005). The Effects of Ripening On the Functional Properties of Plantain and Plantain Based Cake. International Journal of Food Properties, 8: 347-353

[45] Opata, D. D., Asiedu-Larbi, J., Ellis, W. O. and Oduro, I. (2007). Production of Couscous and French Fries from DioscoreaAlata (Water Yam)
Securing livelihood through Yams. Proceeding of a Technical Workshop on Progress in Yam Research for Development in West and Central Africa held in Accra, Ghana, 11 - 13 September 2007, edited by B. Nkamleu, D. Annang, and N.M. Bacco. IFAD TAG 704, IITA Nigeria, page 165

[46] Otegbayo, B., Aina, J., Asiedu, R. and Bokanga, M. (2006). Pasting characteristics of fresh yams (Dioscereaspp.) as indicators of textural quality in a major food product - 'pounded yam'. Food Chemistry 99: 663-669

[47] Premsekhar, M. and Rajashree, V. (2009). Influence of Organic Manures on Growth, Yield and Quality of Okra. American-Eurasian Journal of Sustainable Agriculture, Vol. 3 No. 1: pp. 6-8, ISSN 1995-0748

[48] Tester, R. F. and Morrison, W. R. (1990). Swelling and gelatinization of cereal starches. II. Waxy rice starches. Cereal Chemistry 67 (6): 558563.

[49] Udensi, E. A. and Okoronkwo, K. A. (2006). Effects of fermentation and germination on the physicochemical properties of Mucunacochinchinensisprotein isolate. African Journal of Biotechnology 5 (10): 896-900.

[50]Zakpaa HD, Mak-Mensah EE, Adubofour J (2010). Production and characterization of flour produced from ripe "apem" plantain (Musasapientum L. var. paradisiacal; French horn) grown in Ghana. J. Agric. Biotechnol. Sustainable Dev., 2(6): 92-99.

[51]Zhao, W., Zhai F., Zhang D., An Y., Liu Y., He Y., Ge K. and Scrimshaw N.S. (2004). Lysine fortified wheat flour improves the nutritional and immunological status of wheat eating families in Northern China. Food and Nutrition Bulletin, 25: 114-122.

[52]Zobel, H. F. (1984). Gelatinization of Starch and Mechanical Properties of Starch Pastes. In Starch: Chemistry and Technology. (Eds.) Whistler, R L, BeMiller J.N. and Paschall E F), Academic Press, New York. pp 300-302 